\title{
Interchange and movements of humpback whales (Megaptera novaeangliae) between western North Pacific winter breeding grounds in northern Luzon, Philippines and Okinawa, Japan
}

\author{
Jo Marie V. Acebes ${ }^{1,2 *}$, Haruna Okabe ${ }^{3}$, Nozomi Kobayashi ${ }^{3}$, Shotaro Nakagun ${ }^{1}$, \\ Takeya Sakamoto ${ }^{1}$, Brendon Hirney ${ }^{1}$, NaOto Higashi ${ }^{3}$ and Senzo Uchida ${ }^{3}$ \\ Contact e-mail: jacebes@balyena.org.ph
}

\begin{abstract}
Humpback whales wintering in the northern Philippines and Okinawa, Japan, belong to the western North Pacific subpopulation, now recognised as a distinct population segment. The numbers for this subpopulation are low hence it is being proposed to be listed as endangered. Although previous research revealed movements between breeding grounds, the relationship between these areas remain little understood. Recent survey efforts in the Philippines resulted in a total of 230 photoidentified individuals from 1999-2016 while Okinawa had 1,445 from 1991-2014. Between the seasons a total of 100 matches of 100 individual whales were found between the two breeding grounds including 41 males and 26 females while the sex of the other whales was unknown. Eight individuals were recorded moving within seasons, including two individuals moving across seasons multiple times. The two whales were both males, where one was recorded in both breeding grounds in three different seasons (2005, 2008 and 2012). The shortest duration of recorded sightings between breeding grounds was one whale seen in the Philippines in late March 2012 and in Okinawa 13 days later. The high within-region return index values in the Philippines may indicate a small population utilising this breeding ground with a high rate of return, while the lower return index values in Okinawa may indicate a relatively larger population utilising the Okinawa breeding ground. The interchange index value between Okinawa and the Philippines (0.30) was much lower compared with the average value of within-region return index in the Philippines (3.41). However, 100 out of 230 individuals $(43.48 \%)$ identified in the Philippines were also observed in Okinawa and the interchange index was only marginally lower than the value of within-region return index in Okinawa (0.60). These results may indicate that the two breeding grounds are likely sharing the same subpopulation and yet, at some level, indicates fidelity of the whales to their respective regions. The low survey and sampling effort in the Philippines presented limitations in assessing the extent of linkage with the Okinawa breeding ground. Renewed and strengthened international collaborations are needed, especially among the Asian breeding grounds in order to unravel the complexities of the population structure and migratory movements of this small western North Pacific subpopulation.
\end{abstract}

KEYWORDS: HUMPBACK WHALE; PHOTO-ID; BREEDING GROUND; MIGRATION; SITE FIDELITY; MOVEMENTS; PHILIPPINES; JAPAN

\footnotetext{
${ }^{1}$ BALYENA.ORG, Jagna, Bohol, Philippines.

${ }^{2}$ Zoology Division, National Museum of Natural History, National Museum of the Philippines, Manila, Philippines.

${ }^{3}$ Okinawa Churashima Foundation, Motobu, Okinawa, Japan.
} 


\section{INTRODUCTION}

Humpback whales (Megaptera novaeangliae) are widely distributed in oceans worldwide and migrate from higher latitude feeding grounds in the summer to lower latitude breeding grounds in the winter (Baker et al., 1986; Chittleborough, 1965; Clapham and Mead, 1999; Dawbin, 1966; Katona and Beard, 1990). In the North Pacific, the summer feeding range of humpback whales spans the Okhotsk Sea, Commander Islands, Chukotka Peninsula, Kamchatka, Russia, Aleutian-Bering Sea, Gulf of Alaska, southeast Alaska and North British Columbia, Washington/South British Columbia, California-Oregon coast and waters off California (Calambokidis et al., 2008; Calambokidis et al., 1996; Titova et al., 2018). Five winter breeding grounds are now known in the North Pacific (Calambokidis et al., 2008): in the western North Pacific: (1) the waters of Ogasawara (Bonin Islands) and Okinawa (Ryukyu) in Japan and the Babuyan Islands, northern Philippines, referred to as the Asian breeding ground; (2) a second western North Pacific population whose location is unknown, which is believed to migrate through Ogasawara (Bettridge et al., 2015); in the central North Pacific; (3) around the waters of the main Hawaiian Islands or the Hawaiian breeding ground; in the eastern North Pacific; (4) the Mexican breeding ground which includes the Revillagigedo Islands, Baja, California and the coast of mainland Mexico; and (5) the Central American breeding ground, off the waters of southern Mexico to Costa Rica (Craig and Herman, 1997; Darling and Mori, 1993; Herman, 1980; Herman and Antinoja, 1977; Nishiwaki, 1966; Titova et al., 2018; Urban and Aguayo, 1987) (Fig. 1).

Currently, humpback whales are categorised under the International Union for Conservation of Nature (IUCN) as Least Concern due to signs of increasing populations in areas where data are available (Cooke, 2018). In the North Pacific, the abundance of humpback whales has been estimated to be steadily increasing and is believed to be greater than estimated numbers prior to whaling (Barlow et al., 2011). However, there is still concern regarding small, discrete subpopulations, which includes the Arabian Sea, the West coast of Africa, the South Pacific subpopulations of Oceania, and the western North Pacific subpopulation (Cooke, 2018). In the United States (US), under the recent ruling of the National Marine Fisheries Science (NMFS) for the national Endangered Species Act, 14 distinct population segments (DPS) of humpback whale populations worldwide were designated. The status of the western North Pacific DPS, which constitutes humpback whales wintering in the Philippines, Okinawa, and off Ogasawara was classified as Endangered (NMFS and NOAA, 2016). Recent estimates have shown

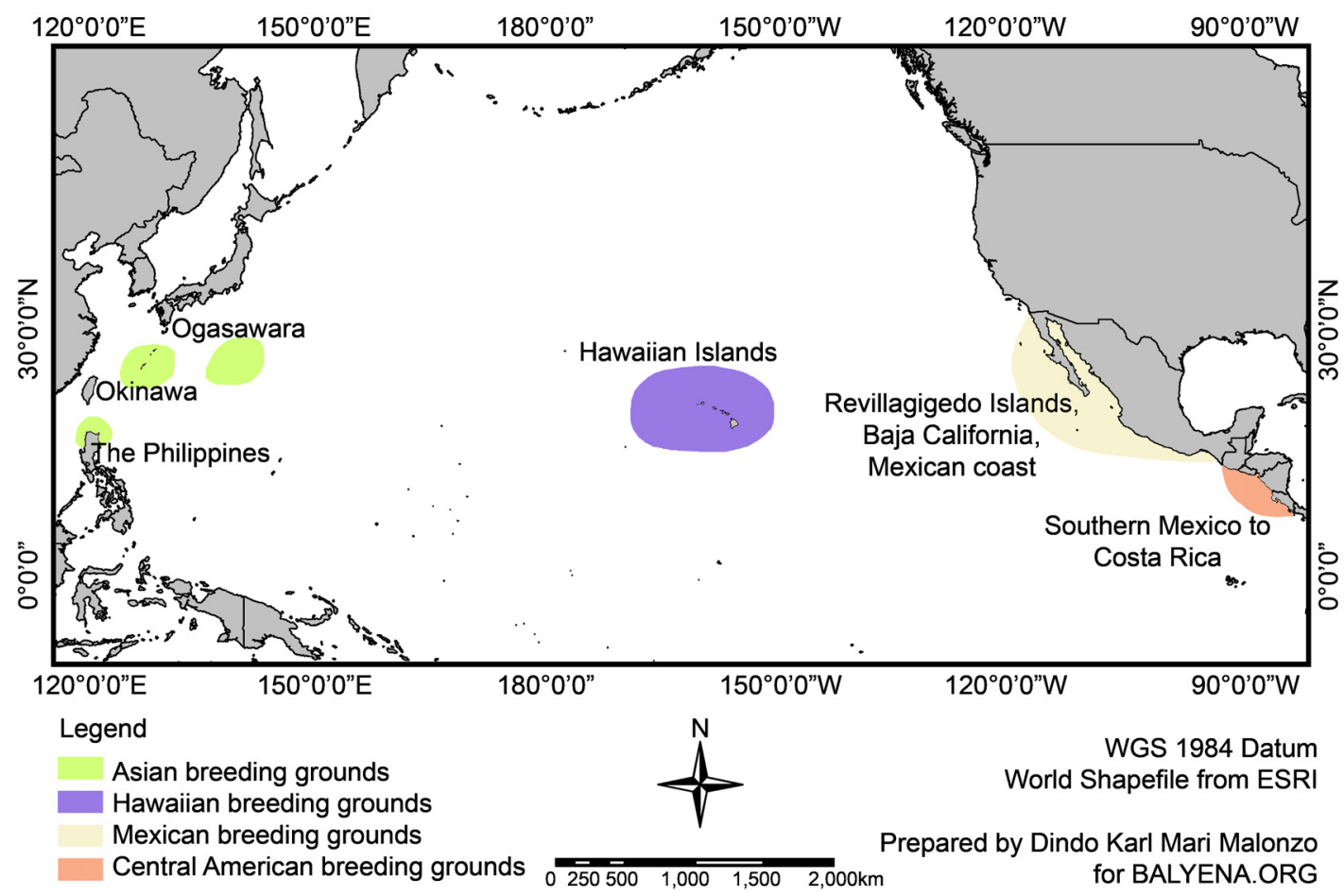

Fig. 1. Map of the known humpback whale breeding grounds in the North Pacific. 
that the western North Pacific population has a low abundance estimate of about 1,000 whales (Calambokidis et al., 2008; Wade et al., 2016) with high incidence of mortality and continues to be subjected to threats (Calambokidis et al., 2008; NMFS and NOAA, 2016). Previous fluke comparison efforts and a study on mitochondrial DNA (mtDNA) diversity through the North Pacific-wide study called Structure of Populations, Levels of Abundance and Status of Humpbacks (SPLASH), conducted from 2004-2006 demonstrated that the migratory patterns and population structure of the North Pacific humpback whales are complex (Baker et al., 2013; Calambokidis et al., 2008) and many questions remain about the relationships between the Okinawa, Ogasawara, and the Philippines assemblies. It is for all the reasons mentioned above that the IUCN expressed concern for the western North Pacific stock (Baker et al., 2013; IUCN, 2009) and it gained an Endangered classification in the US (NMFS and NOAA, 2016).

Although it has been demonstrated in previous work based on photo-identification and genetic studies that the Philippines, Okinawa and Ogasawara are winter breeding destinations for humpback whales in the western North Pacific (Baker et al., 2008; Calambokidis et al., 2008; Titova et al., 2018; Witteveen et al., 2009), the SPLASH study postulated the existence of a second unknown breeding population. The SPLASH data indicated that the whales feeding from the Aleutians and Bering Islands were not well represented in any of the wintering grounds surveyed during their study. Hence, the researchers concluded that these whales must be going to a previously unsampled wintering ground (Baker et al., 2013; Barlow et al., 2011; Calambokidis et al., 2008). This hypothesis was further supported by Titova et al. (2018) who found a low overall match rate of individual whales from Russia and the Aleutians to any of the wintering grounds in the North Pacific.

The recent study on photo-identification matches from the feeding grounds in the Russian Far East and breeding grounds in the North Pacific conducted by Titova et al. (2018) used the catalogues of Okinawa and the Philippines from SPLASH and additional catalogues from 1989-2006 (Okinawa) and 2000-2006 (Philippines). However, humpback whale surveys in Okinawa and the Philippines continued with relative consistency since the end of SPLASH in 2006, therefore increasing the number of photo-identified whales in the respective catalogues. Given the above, an investigation of the interchanges between these breeding grounds using the most updated fluke catalogues is warranted.

The current study presents the most recent results of fluke matches between the breeding grounds in Okinawa and the Philippines using their updated fluke photo-identification catalogues. By looking at the timing and movement patterns of humpback whales within and across seasons it aimed to gain insights into the relationship between these breeding grounds. The possibility of sex segregation, site fidelity, and degree of interchange between breeding grounds were also investigated and discussed.

\section{METHODS}

\section{Study Areas and Small Vessel Surveys}

In the Philippines, the main study site is the Babuyan Marine Corridor, around the Babuyan Islands Chain in northern Luzon, (18 $\left.53^{\prime} \mathrm{N}, 121^{\circ} 36^{\prime} \mathrm{E}\right)$ : Camiguin, Fuga, Babuyan Claro, Calayan and Dalupiri (Acebes et al., 2007) (see Fig. 2). The first two fluke photo-identification photographs of humpback whales were taken in 1999 during an opportunistic sighting around Fuga Island (Yaptinchay, 1999). Dedicated humpback whale surveys began in 2000 (Acebes et al., 2007). Small vessel surveys were conducted between 2000 and 2016 off all the islands in the Babuyan chain. Different islands were surveyed at different times of the season between Feb and May (see Table 1 for details) (Silberg et al., 2013). Predetermined tracklines were followed along the coasts of the islands with track legs running perpendicular and parallel (alternately) to shore (Fig. 3). Waypoints between islands were also set and were followed during on-effort inter-island crossings. The direction (northward or southward) and order of waypoints followed around each island at the beginning of each cruise day was set randomly whenever possible. Once a humpback whale was sighted, the time and location were recorded using a handheld Global Positioning System (GPS) and focal follows were conducted. The fluke(s) were photographed using digital Single Lens Reflex (SLR) cameras with 35-350mm, 100-400 mm and 400mm fixed lenses and the behaviour, composition of the group, and the presence of other cetacean species were recorded. An omni-directional hydrophone was 


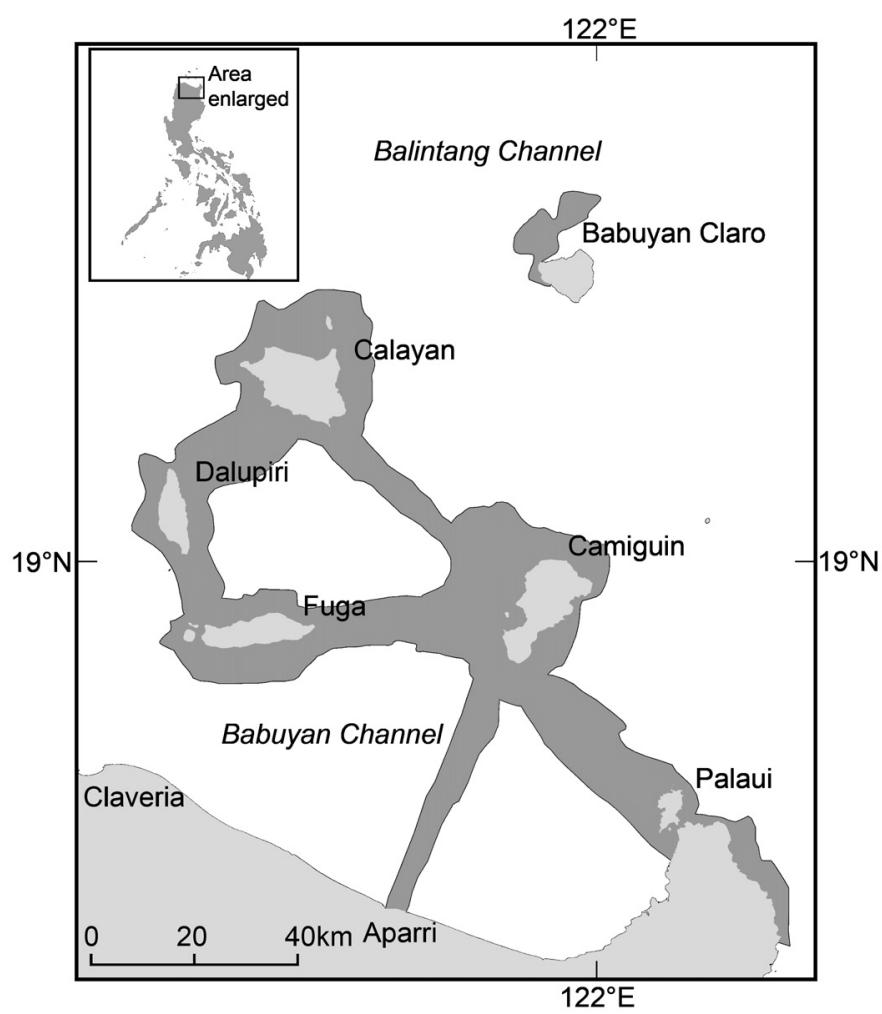

Fig. 2. Map of the study site in the Babuyan Islands, Philippines showing areas surveyed in dark grey.

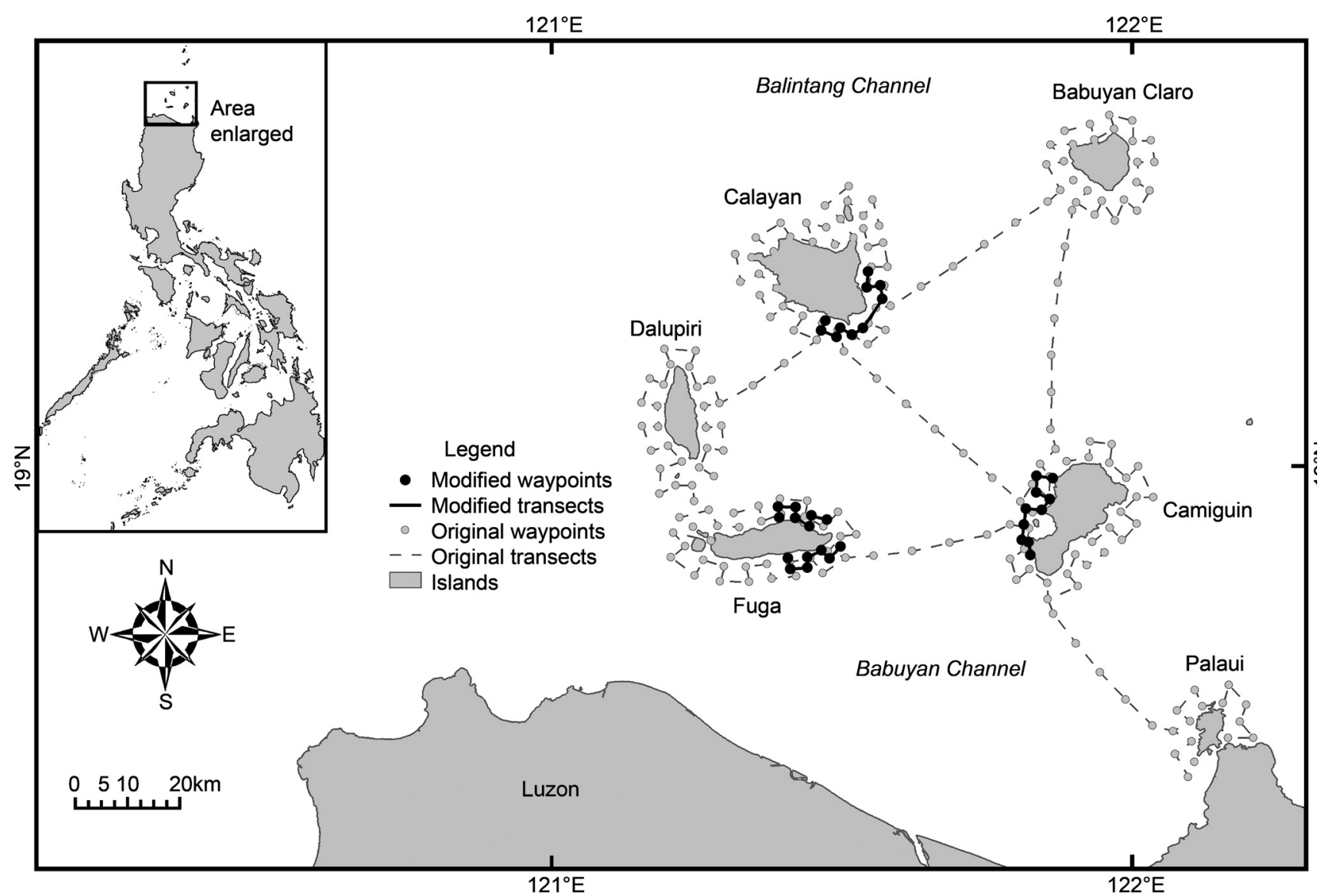

Fig. 3. Map of predetermined waypoints and transects in the Babuyan Islands, Philippines. Original waypoints and transects in black were established in 2000 and were modified (shown in grey) in 2005, and placed closer to shore in areas with higher encounter rates. 
Table 1

Survey effort and number of photo-identified whales per season in the Babuyan Islands, Philippines (2000-16).

\begin{tabular}{|c|c|c|c|c|c|}
\hline Year & Research group & Survey area & Survey season & No. of survey days & No. of IDs \\
\hline 2000 & WWF & Camiguin, Fuga, Dalupiri, Calayan & Apr. & 14 & 0 \\
\hline 2001 & WWF & Camiguin, Fuga, Dalupiri, Calayan, Babuyan Claro & Mar.-Apr. & 43 & 7 \\
\hline 2002 & WWF & Camiguin, Fuga, Dalupiri, Calayan, Babuyan Claro & Mar.-May & 47 & 30 \\
\hline 2003 & WWF & Camiguin, Calayan & Feb.-May & 51 & 38 \\
\hline 2004 & WWF & Camiguin, Calayan & Mar.-Apr. & 33 & 40 \\
\hline 2005 & WWF & Camiguin, Calayan & Feb.-May & 60 & 54 \\
\hline 2006 & WWF & Camiguin, Calayan & Feb.-Apr. & 79 & 42 \\
\hline 2007 & BALYENA.ORG & Camiguin & Mar.-Apr. & 30 & 23 \\
\hline 2008 & BALYENA.ORG & Camiguin & Mar.-Apr. & 29 & 23 \\
\hline 2009 & BALYENA.ORG & Camiguin & Mar-Apr. & 26 & 15 \\
\hline 2010 & BALYENA.ORG & Camiguin & Mar. & 13 & 9 \\
\hline 2011 & BALYENA.ORG & Camiguin & Feb.-Apr. & 28 & 23 \\
\hline 2012 & BALYENA.ORG & Camiguin, Fuga & Mar.-Apr. & 32 & 31 \\
\hline 2013 & BALYENA.ORG & Camiguin & Mar.-Apr. & 28 & 30 \\
\hline 2014 & BALYENA.ORG & Camiguin, Calayan & Mar.-Apr. & 29 & 30 \\
\hline 2015 & BALYENA.ORG & Camiguin & Feb.-Apr. & 36 & 54 \\
\hline 2016 & BALYENA.ORG & Camiguin, Fuga & Feb.-Apr. & 39 & 24 \\
\hline Average & & & & 36.29 & 27.82 \\
\hline
\end{tabular}

dropped at selected waypoints to detect any whales singing. If the song was clear and loud, a recording was made using a digital sound recorder.

The sex of individual whales encountered was inferred by their social behaviour or role (Darling and Bérubé, 2001; Glockner, 1983). A whale observed swimming closely to a calf was assigned as a female and was designated as the calf's mother. A whale observed as an escort or an individual accompanying a female with a calf was assigned as a male (Glockner, 1983). Furthermore, a whale observed singing was assigned as a male while a lone non-singing adult joining the singer was also assigned as a male (Darling and Bérubé, 2001; Glockner, 1983). In groups with more than one adult, such as a competitive group with a mother and a calf, all whales other than the mother-calf pair were assigned as males. Other whales whose social category or role could not be determined were recorded as sex 'unknown'. In a competitive group where the female was not identified, all whales are noted as 'unknown' sex. Single adult or juvenile whales, two adult whales and any other group of adult whales, not observed singing or in a competitive behaviour are also noted as 'unknown'. The sex of some whales was already known through the genetics study done by SPLASH (Baker et al., 2008; Calambokidis et al., 2008).

In Okinawa, humpback whale surveys started in 1991 (Uchida, 1997; Uchida et al., 2005) (see Table 2 for details). Surveys were conducted between January and April, off the coast of Motobu Peninsula and around le island (study area indicated as Motobu: $26^{\circ} 33^{\prime} \mathrm{N}, 127^{\circ} 34^{\prime} \mathrm{E}$ to $26^{\circ} 48^{\prime} \mathrm{N}, 127^{\circ} 56^{\prime} \mathrm{E}$ ) and Kerama Islands (study area indicated as Kerama: $26^{\circ} 03^{\prime} \mathrm{N}, 127^{\circ} 06 \mathrm{E}$ to $26^{\circ} 24^{\prime} \mathrm{N}, 127^{\circ} 31^{\prime} \mathrm{E}$ ) in Okinawa, Japan (Fig. 4). Surveys were conducted in both study areas in water depths of up to $1,000 \mathrm{~m}$. Small vessels $(3.2-4.9 \mathrm{t})$ were used with at least one observer on each side of the vessel. Survey effort during the study period were fairly consistent every season. When whales were sighted, photographs of the underside of their flukes were taken using digital SLR cameras with 18-200mm fixed lens for photo-identification. Similar to the Philippines, the sighting location was recorded using a GPS and the time of sighting and group composition were also recorded. For every group observed, the presence of singers was checked and recorded using a hydrophone. Assigning of the sex of whales was similar to that in the Philippines (Kobayashi et al., 2017; Kobayashi et al., 2016a; Kobayashi et al., 2016b). In addition, some of the whales had definitive sex based on genetic analysis of biopsy samples taken in a previous study.

\section{Photo-Identification}

Fluke photos were graded according to established methods (Calambokidis et al., 2008; Calambokidis et al., 2001; Calambokidis et al., 1997) and the best photos were compared with the existing catalogue of each research group by at least two experienced researchers. Each research group catalogued the fluke photos of newly identified whales by naming them according to their respective identification codes (i.e. Philippines - PH002; Okinawa-R-123). 
Table 2

Survey effort and number of photo-identified whales in Okinawa, Japan (1991-2014).

\begin{tabular}{|c|c|c|c|c|c|}
\hline Year & Research group & Survey area & Survey season & No. of survey days & No. of IDs \\
\hline 1991 & Okinawa Chrashima Foundation & Kerama & Jan.-Apr. & 60 & 44 \\
\hline 1992 & Okinawa Chrashima Foundation & Kerama & Jan.-Apr. & 68 & 38 \\
\hline 1993 & Okinawa Chrashima Foundation & Kerama & Jan.-Apr. & 54 & 51 \\
\hline 1994 & Okinawa Chrashima Foundation & Kerama & Jan.-Apr. & 61 & 65 \\
\hline 1995 & Okinawa Chrashima Foundation & Kerama & Jan.-Apr. & 48 & 64 \\
\hline 1996 & Okinawa Chrashima Foundation & Kerama & Jan.-Apr. & 37 & 73 \\
\hline 1997 & Okinawa Chrashima Foundation & Kerama & Jan.-Apr. & 57 & 100 \\
\hline 1998 & Okinawa Chrashima Foundation & Kerama & Jan.-Apr. & 48 & 83 \\
\hline 1999 & Okinawa Chrashima Foundation & Kerama & Jan.-Apr. & 53 & 80 \\
\hline 2000 & Okinawa Chrashima Foundation & Kerama & Jan.-Apr. & 57 & 107 \\
\hline 2001 & Okinawa Chrashima Foundation & Kerama & Jan.-Apr. & 56 & 102 \\
\hline 2002 & Okinawa Chrashima Foundation & Kerama & Jan.-Apr. & 20 & 101 \\
\hline 2003 & Okinawa Chrashima Foundation & Kerama & Jan.-Apr. & 5 & 76 \\
\hline 2004 & Okinawa Chrashima Foundation & Kerama & Jan.-Apr. & 18 & 118 \\
\hline 2005 & Okinawa Chrashima Foundation & Kerama & Jan.-Apr. & 27 & 128 \\
\hline 2006 & Okinawa Chrashima Foundation & Kerama, Motobu & Jan.-Apr. & 95 & 208 \\
\hline 2007 & Okinawa Chrashima Foundation & Kerama, Motobu & Jan.-Apr. & 77 & 283 \\
\hline 2008 & Okinawa Chrashima Foundation & Kerama, Motobu & Jan.-Apr. & 82 & 232 \\
\hline 2009 & Okinawa Chrashima Foundation & Kerama, Motobu & Jan.-Apr. & 79 & 345 \\
\hline 2010 & Okinawa Chrashima Foundation & Kerama, Motobu & Jan.-Apr. & 80 & 303 \\
\hline 2011 & Okinawa Chrashima Foundation & Kerama, Motobu & Jan.-Apr. & 80 & 429 \\
\hline 2012 & Okinawa Chrashima Foundation & Kerama, Motobu & Jan.-Apr. & 78 & 359 \\
\hline 2013 & Okinawa Chrashima Foundation & Kerama, Motobu & Jan.-Apr. & 68 & 337 \\
\hline 2014 & Okinawa Chrashima Foundation & Kerama, Motobu & Jan.-Apr. & 75 & 429 \\
\hline Average & & & & 57.63 & 173.13 \\
\hline
\end{tabular}

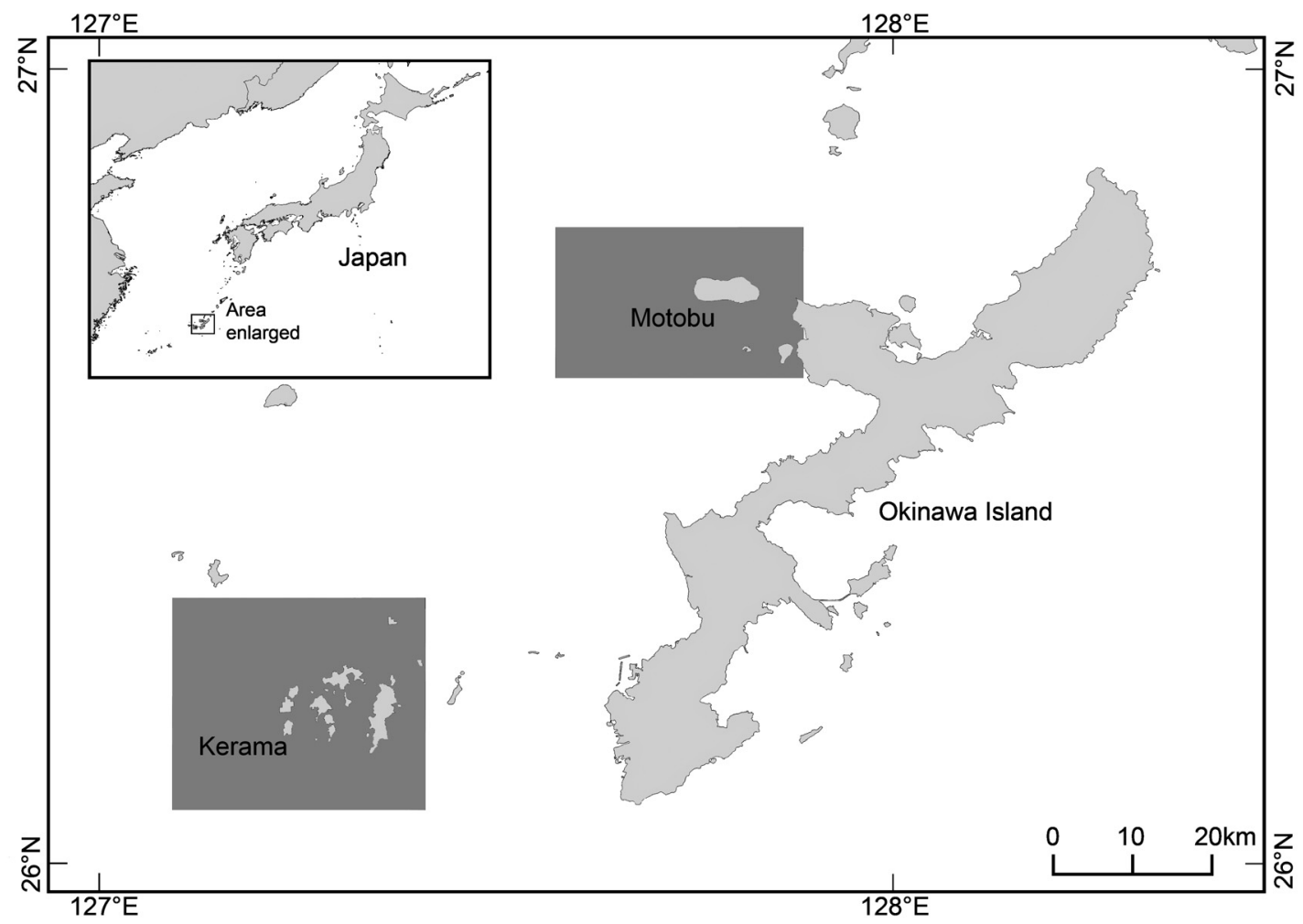

Fig. 4. Map of Motobu and Kerama Islands, Okinawa, Japan showing areas surveyed in dark grey.

For both the Philippines and Okinawa, the updated catalogues were reviewed for possible duplicates in identification and misidentified roles. Three researchers independently compared the two catalogues to search for matches between the two breeding grounds of Okinawa (1991-2014) and the Philippines (1999-2016). For each individual whale that matched between the Philippines and Okinawa, the sighting record was reviewed to 
determine the exact date(s) it was sighted in each study site. Whales that were sighted in the same year in both study sites were noted and the earliest and latest date of sightings in both study sites were recorded in an attempt to determine direction of movement and duration of stay in the respective study sites within a season. The assigned sex or social category of each matched whale was also compared to verify if it was the same for both research groups. When assigned sex conflicts were found between the two breeding grounds, genetic sexing assignments from Okinawa were utilised. The number of males and females among all identified whales in the catalogue of each breeding ground was counted. The percentage of individual males and females that matched between the two breeding grounds was also calculated to determine what percent of the respective sexes in each breeding ground's catalogue matched with each other.

Given the large differences in numbers of photo-identified individuals between the Philippines and Okinawa, with Okinawa having almost six times more whales than the Philippines, the proportion of the whales that have been observed multiple times in each breeding ground was calculated in an attempt to quantify the re-sight rate in each area. The number of times an individual whale was sighted or observed was also counted for the Philippines (1999-2016) and for Okinawa (1991-2014).

To determine the relative degree of interchange and movement of whales, the within-region return index and between-region interchange index were calculated following Calambokidis et al. (2001) and Garrigue et al. (2002). The return index within-region (re-sights within the Philippines and within Okinawa) was calculated as follows:

$$
R i j=M i, j /\left(A i^{*} B i\right) * 1000
$$

Where,

$A i=$ number of whales photo-identified in all the years before 2016 (for the Philippines), or before 2014 (for Okinawa)

$B i=$ number of whales photo-identified in 2016 (for the Philippines), or in 2014 (for Okinawa)

$M i, j=$ number of whales marked in any previous years and re-sighted in 2016 (for the Philippines), or in 2014 (for Okinawa)

The index of interchange between-region was calculated as:

$$
R i j=M i, j /(A 1 * B 2) * 1000
$$

Where,

$$
\begin{aligned}
& A 1=\text { number of whales identified in region } \mathrm{A} \text { (the Philippines) } \\
& B 2=\text { number of whales identified in region } \mathrm{B} \text { (Okinawa) } \\
& M i, j=\text { number of whales re-sighted in both regions }
\end{aligned}
$$

The indices were considered to be zero when there were no whales sighted within or between regions (Garrigue et al., 2002). A high index value occurs where there is a high probability of the same individual whale being recaptured, or a high movement probability to another location (i.e. the result of a small population being present, or high connectivity). In contrast a low value occurs due to either a large population or a low rate of interchange of animals (Calambokidis et al., 2001). Within-region indices for multiple years were calculated for both the Philippines and Japan by using the number of whales photo-identified in the last three years in the respective catalogues (i.e. Philippines 2016, 2015, 2014; Okinawa 2014, 2013, 2012). For each year, the total number of whales photo-identified in all years previous to that year was compared with the number of whales re-sighted in that year (see example in first formula above). The index of interchange between the Philippines (1999-2016) and Ogasawara (1987-2014) was also calculated in the same way, using the photo-identification data presented in Nakagun et al. (2020), in order to analyse relationships between the three breeding areas in the western North Pacific. The same formula above was used for the number of whales photo-identified in the Philippines from 1999-2016 and for Ogasawara from 1987-2014. 


\section{RESULTS}

\section{Total identifications and interchange among and within breeding grounds}

In the Philippines, from 1999-2016, a total of 230 individuals were photo-identified with 71 males, 60 females and 99 of unknown sex. The proportion of re-sights of individuals were 98 out of 230 (42.61\%) and the average value for the within-region return indexes for multiple years was 3.41 (Tables 3 and 4). In Okinawa, a total of 1,445 individuals were photo-identified from 1991-2014 with 127 males, 103 females and the rest of unknown sex. The re-sights of individuals were 809 out of 1,445 individuals (55.99\%) and the average value for the withinregion return indexes for multiple years was 0.60 (see Tables 3 and 4). The number of repeat sightings or re-sights of individual whales in the Philippines and Okinawa are shown in Table 5. A total of 100 matches corresponding to 100 individuals were found between the two breeding grounds, which was $43.48 \%$ of the total identified individuals in the Philippines $(n=230)$ and $6.92 \%$ of the total identified individuals in Okinawa $(n=1,445)$. Out of these 100 matches, 41 were males and 26 were females, while the rest were unknown (see Table 6). The 41 males represent $57.74 \%$ of the males in the Philippines catalogue, while only $32.28 \%$ in the Okinawa catalogue. The 26 females represent $43.33 \%$ of the females in the Philippines catalogue, while only $25.24 \%$ in the Okinawa catalogue. The interchange index value between the Philippines and Okinawa was 0.30 which was much lower than the average within-region return index in the Philippines (3.41) but slightly lower than in Okinawa (0.60) (see Table 4). The interchange index value between the Philippines and Ogasawara was 0.27 which was also slightly lower than the interchange index value between the Philippines and Okinawa (Table 4).

Table 3

Proportion of photo-identified whales observed (re-sighted) in multiple years in the Philippines (1999-2016) and Okinawa (1991-2014).

\begin{tabular}{lccc}
\hline & $\begin{array}{c}\text { Number of unique } \\
\text { whales identified }\end{array}$ & $\begin{array}{c}\text { Number of unique whales } \\
\text { observed in multiple seasons }\end{array}$ & $\begin{array}{c}\text { Proportion of whales re-sighted } \\
\text { in multiple years (\%) }\end{array}$ \\
\hline Philippines & 230 & 98 & 42.61 \\
Okinawa & 1,445 & 809 & 55.99 \\
\hline
\end{tabular}

Table 4

Interchange indices between-regions, the Philippines $(\mathrm{PH})$ and Okinawa $(\mathrm{OK})$ and between the Philippines and Ogasawara (OG), and return indices within-region in the Philippines (PH) and in Okinawa (OK) in multiple years.

\begin{tabular}{cccc}
\hline Area & Interchange index & Years (PH) & Years in Japan \\
\hline Philippines - Okinawa & 0.30 & $1999-2016$ & $1991-2014$ \\
Philippines - Ogasawara & 0.27 & $1999-2016$ & $1987-2014$ \\
\hline Philippines & Within-region index & Years & \\
\hline & 3.67 & $1999-2016$ \\
Average & 3.04 & $1999-2015$ & \\
Okinawa & 3.54 & $1999-2014$ & \\
\hline & 3.41 & Years & \\
\hline & Within-region index & $1991-2014$ \\
& 0.55 & $1991-2013$ \\
\end{tabular}

Table 5

Re-sights of unique individual whales in the Philippines (1999-2016) and Okinawa (1991-2014).

\begin{tabular}{|c|c|c|c|c|c|c|c|c|c|c|c|c|}
\hline & \multicolumn{11}{|c|}{ Number of times unique whales were observed } & \multirow[b]{2}{*}{ Total } \\
\hline & $1 \mathrm{x}$ & $2 x$ & $3 x$ & $4 \mathrm{x}$ & $5 x$ & $6 x$ & $7 x$ & $8 x$ & $9 x$ & $10 x$ & $10 x+$ & \\
\hline No. of unique whales observed, Philippines (1999-2016) & 131 & 43 & 26 & 10 & 6 & 2 & 6 & 2 & 1 & 2 & 1 & 230 \\
\hline No. of unique whales observed, Okinawa (1991-2014) & 636 & 261 & 168 & 100 & 80 & 62 & 36 & 27 & 22 & 14 & 39 & 1,445 \\
\hline
\end{tabular}


Table 6

Number of individual whales photo-identified in the Philippines and Okinawa and their sex, if known.

\begin{tabular}{|c|c|c|c|c|c|c|c|c|}
\hline & \multicolumn{4}{|c|}{ Number of unique whales photo-identified in each area } & \multicolumn{4}{|c|}{ Number of unique whales observed in both areas } \\
\hline & \multirow[b]{2}{*}{ Total } & \multicolumn{3}{|c|}{ Sex } & \multirow[b]{2}{*}{ Total } & \multicolumn{3}{|c|}{ Sex } \\
\hline & & Male & Female & Unknown & & Male & Female & Unknown \\
\hline Philippines & 230 & 71 & 60 & 99 & & & & \\
\hline Okinawa & 1,445 & 127 & 103 & 1,215 & 100 & 41 & 26 & 33 \\
\hline
\end{tabular}

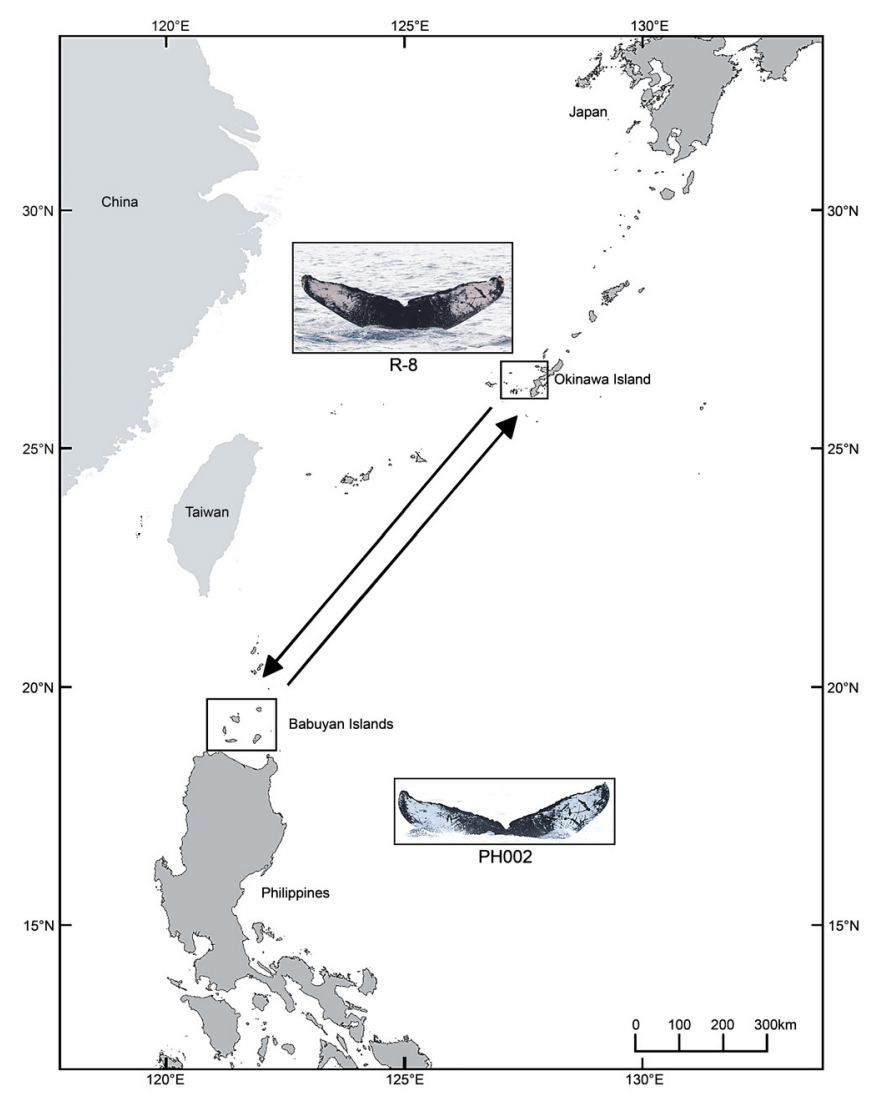

Fig. 5. Fluke photograph of PH002/R-8, the male humpback whale that moved between the Philippines and Okinawa within three different seasons.

\section{Within season movements between breeding grounds}

Based on photo-identification, eight individuals were seen in both breeding grounds within the same season (see Table 7). Four of them were confirmed males. Multiple within-season migrations were documented for two males. One of them (PH002/R-8) moved between the two breeding grounds in three different seasons (2005, 2008, 2012) (Fig. 5, Table 7).

The shortest duration of recorded sightings between grounds was with one whale seen in the Philippines in late March 2012 and in Okinawa 13 days later. Most of the whales were first observed in Okinawa then in the Philippines ( $n=5$ individuals in 7 years) than reverse ( $n=4$ individuals in 4 years). The movement from Okinawa to the Philippines was undergone by four males and one unknown while the reverse was done by two females, one male and one unknown.

\section{Arrival and departure times}

The earliest arrival of whales in Okinawa was 28 October based on reports from the local people while the earliest whale arrival documented through photo-identification was 21 December. The latest observed departure of humpback whales from Okinawa was 1 June. In the Philippines, according to island residents, whales arrive as 
Table 7

Within-season movements of whales between Okinawa (OK) and the Philippines (PH), number of days between observations and direction of movements.

\begin{tabular}{|c|c|c|c|c|}
\hline Whale ID & Sex & $\mathrm{OK} \rightarrow \mathrm{PH}$ & $\mathrm{PH} \rightarrow \mathrm{OK}$ & $\begin{array}{c}\text { No. of days in between } \\
\text { observations }\end{array}$ \\
\hline \multirow[t]{3}{*}{$\mathrm{PH} 002 / \mathrm{R}-8$} & $\mathrm{M}$ & 2005/Feb. 25-Apr. 5 & & 39 \\
\hline & & 2008/Feb. 1-Mar. 10 & & 38 \\
\hline & & & 2012/Mar. 9-Mar. 22 & 13 \\
\hline PH068/R-123 & $\mathrm{F}$ & & 2013/Mar. 11-Mar. 26 & 15 \\
\hline PH233/R-262 & & 2014/Feb. 18-Mar. 25 & & 35 \\
\hline PH108/R-263 & $\mathrm{F}$ & & 2014/Mar. 5-Mar. 29 & 24 \\
\hline PH135/R-323 & $M$ & 2005/Feb. 3-Apr. 21 & & 77 \\
\hline \multirow[t]{2}{*}{ PH023/R-346 } & $\mathrm{M}$ & 2011/Feb. 9-Mar. 20 & & 39 \\
\hline & & 2013/Feb. 17-Mar. 20 & & 31 \\
\hline PH007/R-579 & $\mathrm{M}$ & 2006/Mar. 4-Apr. 3 & & 30 \\
\hline PH215/R-1327 & Un & & 2013/Mar. 19-Apr. 4 & 16 \\
\hline
\end{tabular}

early as November (Acebes et al., 2007). However, based on reports of trained informants, the earliest reported sighting was in January. The latest observed sighting is on the second week of May while the latest reported sighting was on the first week of July (Acebes et al., 2007).

Among the matched whales that moved between the Philippines and Okinawa within the same season, the earliest in the season a whale was sighted in Okinawa was 27 January 2006 that was then last seen in Okinawa on 4 March 2006 (see Table 7). On 6 April 2006, it was sighted in the Philippines. On the other hand, the latest in the season a matched whale was seen in the Philippines was on 21 April 2005 (see Table 7). This whale (PH135/R-323) was seen in the beginning of the season in Okinawa on 3 February 2005. Based on our data, south-bound movement of humpback whales from their Okinawa breeding ground to the Philippines commences in February, lasting for an average of 41.3 days while the north-bound movement from the Philippines begins in March onwards and lasts for an average of 17.0 days (Table 7).

\section{DISCUSSION}

This study is the first comprehensive photo-ID matching between Okinawa and the Philippines using updated catalogues post-SPLASH (Calambokidis et al., 2008). In 2006, at the end of SPLASH, the catalogues of photoidentified whales from the Philippines and Okinawa contained 138 and 609 individual whales, respectively. The increase in the number of photo-identified whales in the catalogues of both wintering grounds is significant. The total number of matches between the two areas are also higher than previous studies done on the western North Pacific population (Calambokidis et al., 2008; Titova et al., 2018). With SPLASH, in the 2004-2006 seasons, 77 unique identifications from the Philippines were compared with 215 unique identifications from Okinawa and resulted in 5 matches (Calambokidis et al., 2008).

The proportion of whales re-sighted or observed in multiple years was slightly higher in Okinawa, with $55.99 \%$ compared with $42.61 \%$ in the Philippines. On the other hand, the average return index of animals annually re-sighted in the Philippines (3.41) was much higher than in Okinawa (0.60). It should be noted that the withinregion return index values could be biased given the relatively small total number of photo-identified whales in an area. For example, the within-region return index value for Okinawa presented in this study, 0.60 from a total of 1,445 individuals, was much lower than the value presented in Calambokidis et al. (2001) (11.64 from a total of 68 individuals) given that the total number of individuals back then was significantly smaller than the present study. Therefore, the opposite trend shown in the proportion of whale re-sights and within-region indexes between the Philippines and Okinawa was possibly due to the difference in total number of photo-identified whales between the two areas. Overall, the values of within-region return indexes in each area may indicate a small population utilising the breeding ground in the Philippines with a high rate of return and a relatively larger population utilising the breeding ground in Okinawa. The interchange index value between Okinawa and the Philippines (0.30) was much lower compared with the average value of within-region return index in the Philippines (3.41). However, 100 out of 230 individuals (43.48\%) identified in the Philippines were also observed 
in Okinawa and the interchange index was only marginally lower than the value of within-region return index in Okinawa (0.60). These results may indicate that the two breeding grounds are likely sharing the same subpopulation and yet, at some level, this also indicates fidelity of the whales to their respective regions.

The overall lower number of photo-identified whales in the Philippines compared to Okinawa could be attributed largely to the differences in survey effort time and area covered. The Philippines has a significantly lower survey effort than Okinawa. Surveys in the Philippines only began in 2000 with a total of 17 survey seasons compared to 24 seasons in Okinawa (see Table 1). The number of cruise days per season in the Philippines varied from as short as 13 days to as long as 79 days, averaging to 36 survey days per season and only an average of 27 photo-identified whales per season. Surveys begin relatively late in the season (February) when the whales are known to arrive as early as November (Acebes et al., 2007). The survey area coverage is also much smaller, mainly covering only the waters around the western coast of one island, Camiguin Island, of about $200 \mathrm{~km}^{2}$ for most seasons. This is only a fraction of the total area of the waters surrounding the Babuyan Islands, approximately $9,644 \mathrm{~km}^{2}$, where the whales have been studied since 2000 . Sightings of humpback whale mother-calf pairs have also been recorded a few kilometers south of the Islands, in the eastern coast of northern Sierra Madre in Luzon in 2003 (Silberg et al., 2013), as well as off Pagudpud in llocos Norte in 2012, on the western edge of the northern coast of Luzon. In Okinawa, the surveys have been conducted for much longer and with greater effort (see Table 2). Typically, 60 cruise days, or an average of 57 cruise days were spent around both sites, Motobu and Kerama Islands per season. An average of 173 whales were photo-identified per season. The surveyed area was a total of $2,200 \mathrm{~km}^{2}$ (Motobu $1,000 \mathrm{~km}^{2}$ and Kerama $1,200 \mathrm{~km}^{2}$ ), more than ten times the size of the area surveyed in most seasons in the Philippines. The difference in survey effort between locations make these comparisons difficult to interpret.

The low numbers of photo-identified individuals in the Philippines do not necessarily mean there are less whales utilising this wintering ground but could mean that many animals have been missed. There are also a number of whales that are not photo-identified because the fluke photographs do not pass photo-identification standards or the whale did not show its fluke (i.e. females with young calves). Lower numbers also mean lesser chances of matching with Okinawa and other breeding or even feeding grounds. However, the low matches of whales from the Philippines in Okinawa may also indicate the possibility of some individuals remaining in the Okinawa area during the entire breeding season without moving further south to the Philippines. Given the data available this cannot be determined but is worth investigating in the future.

Even though many of the individual whales in the Philippines were also observed in Okinawa, more than half of the individuals in the Philippines catalogue did not match with Okinawa and most of the individuals in Okinawa did not match with the whales in the Philippines. A recent study between the Philippines and Ogasawara breeding grounds demonstrated similar results wherein a considerable portion of the whales observed in the Philippines were also observed in Ogasawara while the majority of the whales in Ogasawara stayed within its waters (Nakagun et al., 2020). Furthermore, as shown in this study, the interchange index between Ogasawara (19872014) and the Philippines (1999-2016) based on data presented in Nakagun et al. (2020), resulted in a value (0.27), slightly lower than the interchange index between Okinawa and the Philippines (0.30). This further supports the idea that these breeding grounds are likely sharing the same subpopulation but the whales exhibit some degree of fidelity to their respective grounds.

It has also been postulated that there is another breeding ground in the western North Pacific, the Mariana archipelago (Hill et al., 2020). The recent study by Hill et al. (2020), suggested that based on photo-identifications and genetics, the Mariana archipelago is part of the western North Pacific population. Comparison with Ogasawara, Okinawa and the Philippines, showed that most of the Mariana whales matched with Ogasawara (7 individuals) followed by Okinawa (4 individuals) and one with the Philippines (Hill et al., 2020). The authors (Ibid.) further postulated that based on the high mtDNA haplotype diversity and significant mtDNA haplotype frequency differentiation of the Mariana whales compared to the Okinawa and the Philippines SPLASH samples (Baker et al., 2013), two western North Pacific breeding populations may exist, but more genetic samples from the Philippines and the Mariana archipelago are needed to ascertain if this is indeed the Mariana archipelago. 
The slightly higher number of males than females in the catalogues of both the Philippines and Okinawa may indicate a male-bias in these breeding grounds. This male-biased sex-segregation of humpback whales in breeding grounds has been noted in previous studies and may also present a plausible explanation for the higher number of males among the individual whales that matched between Okinawa and the Philippines (Brown et al., 1995; Craig and Herman, 1997). It has been suggested that, at least in some areas, not all females complete their migration to the breeding grounds when they become pregnant en route and return early, or some females may overwinter or stay in the feeding grounds (Ibid.). This may also indicate that the males tend to move between the two breeding grounds more frequently than the females. In Okinawa, the males move between Motobu and Kerama Island more often than females and females with a calf, and the percentage of local movement within the males was significantly higher than for females (Kobayashi et al., 2017). This difference in mobility may be to increase the male's probability of encountering potential mates as they move between the Philippines and Okinawa. This increased mobility as a mating strategy has been indicated by Cercio et al. (1998) in the Hawaiian Islands where they showed higher inter-island recaptures of males while off eastern Australia, migrating males were shown to circle back North on their way to their southern feeding grounds (Burns et al., 2014).

It should be noted however, that there are potential sources of bias that could favour photographic capture of males not investigated during this study, such as the probability of fluke up dives (Craig and Herman, 1997). In the Philippines, it is common to have encounters with females with young calves that do not fluke up hence, no fluke photograph is taken. Although dorsal fin photographs may be used to identify the female in such cases, it cannot be used reliably for re-capturing or comparison with the existing catalogue. Furthermore, $43 \%(n=100)$ of the whales in the catalogue of the Philippines have unknown sex. This is mainly because there has been no extensive biopsy sampling and genetics study done in the Philippines to date.

The distance between the two breeding grounds is approximately 1,000kms (Fig. 5). Multiple within season movements of male whales, as mentioned earlier, could indicate that males are likely to move longer distances to increase chances of mating (Kobayashi et al., 2017). Interchanges of individuals among the three Asian breeding grounds (Philippines, Okinawa and Ogasawara) have been previously demonstrated through photoidentification, including one whale (FG9901/R-19/O-560) that was seen within one season in the Philippines and Ogasawara (Acebes et al., 2007; Yamaguchi et al., 2002; Yamaguchi et al., 1995). This is a distance of over $2,000 \mathrm{kms}$ traveled by a whale in 49 days (Acebes et al., 2007). Song comparisons among these breeding grounds as well as with Hawaii and Mexico have also shown evidence for the mixing of whales, at least males, in these western-central Pacific populations (Darling et al., 2014). This further shows that movement within the Asian breeding grounds is not uncommon.

According to the dates the photo-identified whales were sighted, in the beginning of the wintering season, the whales were observed earlier in Okinawa and then observed in the Philippines later in the season. Towards the end of the season, the whales were observed leaving earlier from the Philippines and then in Okinawa later in the season. This may indicate that during the whales' migration from feeding grounds to the Asian breeding grounds, the whales stop at Okinawa first and then migrate further South to the Philippines. Similarly, on their way back to their feeding grounds, some whales coming from the Philippines may stop at Okinawa before proceeding North. It is also possible that some whales do not stop at Okinawa and move straight back to the feeding grounds.

Previous studies show temporal trends in occurrence of humpback whales in Okinawan waters, which noted an order of migration of humpback whales depending on the whales' social category or sex and the month of the season, with a corresponding increase or decrease in numbers of whales observed (Kobayashi et al., 2016a; Nishiwaki, 1959; 1960; 1961). According to Kobayashi et al. (2016a), in Okinawa, females tended to occur from late January to late February which is the beginning of the breeding season while male occurrence tended to increase from mid-February, remaining high in late February when females were rarely found, resulting in high male proportion in Okinawa after late February. Singing male individuals also tended to increase in early March which could indicate that males are probably staying longer to increase their chances of mating with females still in the area (Ibid.). Something similar may be happening in the Philippines wherein surveys begin from late February and could be another possible explanation for the slight skew towards males observed in the breeding 
ground. Extended surveys covering the entire breeding season are needed to determine if such temporal trends and sex-segregated migration also occurs in the Philippines.

Further research is needed to establish site fidelity to particular breeding grounds and the extent of linkage between the Philippines and Okinawa. The timing of arrivals and departures in Okinawa and the Philippines and signals of movements between these areas require greater survey effort. This study demonstrates the need to increase the survey effort and biopsy sampling in the Philippines to increase the number of photo-identification and genetic samples, as well as decrease the likelihood of missing whales during the breeding season. The use of satellite telemetry in these sites is highly recommended to provide better understanding on the movement of individuals, breeding behaviour, population structure, habitat utilisation and connectivity patterns of the whales (Cercio et al., 2016). This is particularly significant considering that the western North Pacific DPS has been assessed as in danger of extinction throughout its range (NMFS and NOAA, 2016). Furthermore, this highlights the need for renewed and continued close collaboration among researchers in all Asian wintering grounds, including Ogasawara, in order to have a more comprehensive understanding of the place of this subpopulation in the North West Pacific Ocean.

This close but complex linkage between geographically separated, migrating threatened animals shows the need for transboundary research and collaboration. Whales utilising these breeding grounds face different as well as similar threats, including unregulated coastal development, increasing whale watching tourism, entanglement in fishing gear, increased ship traffic and climate change. Results gained in this study are crucial in solving these issues while the complexity of the western North Pacific subpopulations structure is disentangled. As these whales move between and within different countries with varying socio-political contexts and management instruments, the conservation of these migrating whales poses challenges to the entire North Pacific.

\section{ACKNOWLEDGMENTS}

We express our gratitude to the captains of the research vessels K. Toyama, Y. Taira, H. Miyahira, K. Miyahira, and Y. Miyamura, as well as K. Tamura, K. Tomiyama, G. Matsumoto, M. Aiba and all other humpback whale research staff of Okinawa Churashima Foundation and Okinawa Churaumi Aquarium, Okinawa Japan. Research activities in Okinawa have been supported by JSPS KAKENHI Grant Number 19K16239. In the Philippines, we thank Timothy Gardner, Elson Aca, Darius Macusi, Junel Tagarino, Cynthia Layusa, Edna Sabater, Julia Motoomull, Cameron Hookey, Kelly Dolan, Maita Verdote, Patricia Talaue; our boat captain, Harlie Aguinaldo and his crew; all the survey volunteers, researchers, and supporters of BALYENA.ORG. Thanks to Leonard Soriano and Dindo Karl Malonzo for preparing the maps for this manuscript. We also thank the Local Government Unit of Calayan, Bureau of Fisheries and Aquatic Resources - Region II and the Department of Environment and Natural Resources - Region II. Research activities in the Philippines have been supported by the Rufford Small Grants Foundation, Ocean Park Conservation Foundation - Hong Kong, Center for Rural Empowerment and the Environment, Whale Trust, Conservation Sew Mates and BALYENA.ORG. We thank Dr. Jim Darling for reviewing our manuscript.

\section{REFERENCES}

Acebes, J.M.V., Darling, D.J. and Yamaguchi, M. 2007. Status and distribution of humpback whales (Megeptera novaeangliae) in northern Luzon, Philippines. J. Cetacean Res. Manage. 9(1): 37-43.

Baker, C.S., Herman, L.M., Perry, A., Lawton, W.S., Straley, J.M., Wolman, A.A., Kaufman, G.D., Winn, H.E., Hall, J.D., Reinke, J.M. and Ostman, J. 1986. Migratory movement and population structure of humpback whales, Megaptera novaeangliae, in the central and eastern North Pacific. Mar. Ecol. Prog. Ser. 31: 105-19. [Available at: https://doi.org/10.1007/978-1-4615-3406-8_32].

Baker, C.S., Steel, D., Calambokidis, J., Barlow, J., Burdin, A.M., Clapham, P.J., Falcone, E.A., Ford, J.K.B., Gabriele, C.M., Gozález-Peral, U., LeDuc, R., Mattila, D., Quinn, T.J., Rojas-Bracho, L., Straley, J.M., Taylor, B.L., Urbán-R, J., Vant, M., Wade, P., Weller, D., Witteveen, B.H., Wynne, K. and Yamaguchi, M. 2008. geneSPLASH: An initial, ocean-wide survey of mitochondrial (mt) DNA diversity and population structure among humpback whales in the North Pacific. Final report for Contract 2006-0093-008 to the National Fish and Wildlife Foundation, USA.

Baker, C.S., Steel, D., Calambokidis, J., Falcone, E., González-Peral, U., Barlow, J., Burdin, A.M., Clapham, P.J., Ford, J.K.B., Gabriele, C.M., Mattila, D., Rojas-Bracho, L., Straley, J.M., Taylor, B.L., Urbán, J., Wade, P.R., Weller, D., Witteveen, B.H. and Yamaguchi, M. 2013. Strong maternal fidelity and natal philopatry shape genetic structure in North Pacific humpback whales. Mar. Ecol. Prog. Ser. 494: 291-306.

Barlow, J., Calambokidis, J., Falcone, E.A., Baker, C.S., Burdin, A.M., Clapham, P.J., Ford, J.K.B., Gabriele, C.M., LeDuc, R., Mattila, D.K., Quinn II, T.J., Rojas-Bracho, L., Straley, J.M., Taylor, B.L., Urban R., J., Wade, P., Weller, D., Witteveen, B.H. and Yamaguchi, M. 2011. 
Humpback whale abundance in the North Pacific estimated by photographic capture-recapture with bias correction from simulation studies. Mar. Mamm. Sci. 27(4): 793-818. [Available at: https://doi.org/10.1111/j.1748-7692.2010.00444.x].

Bettridge, S., Baker, C.S., Barlow, J., Clapham, P.J., Ford, M., Gouveia, D., Mattila, D.K., Pace, R.M., III, Rosel, P.E., Silber, G.K. and Wade, P.R. 2015. Status review of the humpback whale (Megaptera novaeangliae) under the endangered species act. NOAA Tech. Mem. NOAA-TM-NMFS-SWFSC-540: 263pp.

Brown, M.R., Corkeron, P.J., Hale, P.T., Schultz, K.W. and Bryden, M.M. 1995. Evidence for a sex-segregated migration in the humpback whale (Megaptera novaeangliae). Proc. R. Soc. B 259: 229-34. [Available at: https://doi.org/10.1017/S0952836902003151].

Burns, D., Brooks, L., Harrison, P., Franklin, T., Franklin, W., Paton, D. and Clapham, P. 2014. Migratory movements of individual humpback whales photographed off the eastern coast of Australia. Mar. Mamm. Sci. 30: 562-78. [Available at: https://doi.org/10.1111/ mms.12057].

Calambokidis, J., Falcone, E.A., Quinn, T.J., Burdin, A.M., Clapham, P.J., Ford, J.K.B., Gabriele, C.M., LeDuc, R., Mattila, D., Rojas-Bracho, L., Straley, J.M., Taylor, B.L., Urbán R., J., Weller, D., Witteveen, B.H., Yamaguchi, M., Bendlin, A., Camacho, D., Flynn, K., Havron, A., Huggins, J. and Maloney, N. 2008. SPLASH: Structure of Populations, Levels of Abundance and Status of Humpback Whales in the North Pacific. Final report for Contract AB133F-03-RP-00078, [Available from Cascadia Research, Olympia, WA].

Calambokidis, J., Steiger, G.H., Evenson, J.R., Flynn, K.R., Balcomb, K.C., Claridge, D.E., Bloedel, P., Straley, J.M., Baker, C.S., von Ziegesar, O., Dahleim, M.E., Waite, J.M., Darling, J.D., Ellis, G. and Green, G.A. 1996. Interchange and isolation of humpback whales off California and other North Pacific feeding grounds. Mar. Mamm. Sci. 12(2): 215-26.

Calambokidis, J., Steiger, G.H., Straley, J., Herman, L.M., Cerchio, S., Salden, D., Urbán R, J., Jacobsen, J.K., von Zeigesar, O., Balcomb, K.C., Gabriele, C.M., Dahlheim, M.E., Uchida, S., Ellis, G., Miyamura, Y., Ladrón de Guevara P, P., Yamaguchi, M., Sato, F., Mizroch, S.A., Schlender, L., Rasmussen, K., Barlow, J. and Quinn II, T.J. 2001. Movements and population structure of humpback whales in the North Pacific. Mar. Mamm. Sci. 17(4): 769-94.

Calambokidis, J., Steiger, G.H., Straley, J.M., Quinn Ii, T.J., Herman, L.M., Cerchio, S., Salden, D.R., Yamaguchi, M., Sato, F., Urbán R, J., Jacobsen, J., von Ziegesar, O., Balcomb, K.C., Gabriele, C.M., Dahlheim, M.E., Higashi, N., Uchida, S., Ford, J.K.B., Miyamura, Y., Ladrón de Guevara P, P., Mizroch, S., Schlender, A. and Rasmussen, K. 1997. Abundance and population structure of humpback whales in the North Pacific basin. Contract report submitted to NMFS. 72pp.

Cercio, S., Gabriele, C.M., Norris, T.F. and Herman, L.M. 1998. Movement of humpback whales between Kauai and Hawaii: implications for population structure and abundance estimation in the Hawaiian Islands. Mar. Ecol. Prog. Ser. 175: 13-22.

Cercio, S., Trudelle, L., Zerbini, A.N., Charrassin, J.-B., Geyer, Y., Mayer, F.X., Adrianarivelo, N., Jung, J.-L., Adam, O. and Rosenbaum, H.C. 2016. Satellite telemetry of humpback whales off Madagascar reveals insights on breeding behavior and long-range movements within the southwest Indian Ocean. Mar. Ecol. Prog. Ser. 562: 193-209.

Chittleborough, R.G. 1965. Dynamics of two populations of the humpback whale, Megaptera novaeangliae (Borowski). Austr. J. Mar. Freshw. Res. 16(1): 33-128.

Clapham, P.J. and Mead, J.G. 1999. Megaptera novaeangliae. Mammalian Species 604: 1-9.

Cooke, J.G. 2018. Megaptera novaeangliae. The IUCN Red List of Threatened Species 2018: e.T13006A50362794. [Available at: https://doi.org/10.2305/IUCN.UK.2018-2.RLTS.T13006A50362794.en].

Craig, A.S. and Herman, L.M. 1997. Sex differences in site fidelity and migration of humpback whales (Megaptera novaengliae) to the Hawaiin Islands. Can. J. Zool. 75(11): 1,923-33.

Darling, J.D., Acebes, J.M.V. and Yamaguchi, M. 2014. Similarity yet a range of differences between humpback whale songs recorded in the Philippines, Japan and Hawaii in 2006. Aquat. Biol. 21: 93-107. [Available at: https://doi.org/10.3354/ab00570].

Darling, J.D. and Bérubé, M. 2001. Interactions of singing humpback whales with other males. Mar. Mamm. Sci. 17(3): 570-84. [Available at: $h t t p s: / / d o i . o r g / 10.1111 / j .1748-7692.2001 . t b 01005 . x]$.

Darling, J.D. and Mori, K. 1993. Recent observations of humpback whales (Megaptera novaeangliae) in Japanese waters off Ogasawara and Okinawa. Canadian Journal of Zoology - Revue Canadienne de Zoologie 71(2): 325-33.

Dawbin, W.H. 1966. The seasonal migratory cycle of humpback whales. pp.145-70. In: K.S. Norris (eds). Whales, Dolphins, and Porpoises. University of California Press, Berkeley and Los Angeles. xv+789pp.

Garrigue, C., Aguayo, A., Amante-Helwig, V.L.U., Baker, C.S., Caballero, P., Clapham, P., Constantine, R., Denkinger, J., Donoghue, M., FlorezGonzalez, L., Greaves, J., Hauser, N., Olavarria, C., Pairoa, C., Peckham, H. and Poole, M. 2002. Movements of humpback whales in Oceania, South Pacific. J. Cetacean Res. Manage. 4(3): 255-60.

Glockner, D.A. 1983. Determining the sex of humpback whales in their natural environment. pp.447-64. In: Payne, R. (eds). Communication and Behavior of Whales. AAAS Selected Symposium 76. Westview Press, Boulder, Colorado. xii+643pp.

Herman, L.M. 1980. The 1976/1977 migration of humpback whales into Hawaiian waters: composite description. Final report to US Marine Mammal Commission - NTIS no. PB80-162332 (unpublished). 55pp.

Herman, L.M. and Antinoja, R.C. 1977. Humpback whales in the Hawaiian breeding waters: population and pod characteristics. Scientific Reports of the Whales Research Institute, Tokyo 29: 59-85.

Hill, M.C., Bradford, A.L., Steele, D., Baker, C.S., Ligon, A.D., Ü, A.C., Acebes, J.M.V., Filatova, O.A., Hakala, S., Kobayashi, N., Morimoto, Y., Okabe, H., Okamoto, R., Rivers, J., Sato, T., Titova, O.V., Uyeyama, R.K. and Oleson, E.M. 2020. Found: a missing breeding ground for endangered western North Pacific humpback whales in the Mariana Archipelago. Endanger. Species Res. 41: 91-103. [Available at: https://doi.org/10.3354/esr01010].

Katona, S.K. and Beard, J.A. 1990. Population size, migrations and feeding aggregations of the humpback whale (Megaptera novaeangliae) in the western North Atlantic Ocean. Rep. Int. Whal. Commn (special issue) 12: 295-305.

Kobayashi, N., Okabe, H., Kawazu, I., Higashi, N., Kato, K., Miyahara, H., Nakamura, G., Kato, H. and Uchida, S. 2017. Distribution and local movement of humpback whales in Okinawan waters depend on sex and reproductive status. Zool. Sci. 34: 58-63. [Available at: https://doi.org/10.2108/zs160012]. 
Kobayashi, N., Okabe, H., Kawazu, I., Higashi, N., Miyahara, H., Kato, H. and Uchida, S. 2016a. Peak mating and breeding period of the humpback whale. Open J. Anim. Sci. 6: 169-79. [Available at: $h t t p: / / d x . d o i . o r g / 10.4236 / o j a s .2016 .63022]$.

Kobayashi, N., Okabe, H., Kawazu, I., Higashi, N., Miyahara, H., Kato, H. and Uchida, S. 2016b. Spatial distribution and habitat use patterns of humpback whales in Okinawa, Japan. Mamm. Study 41: 207-14. [Available at: https://doi.org/10.3106/041.041.0405].

Nakagun, S., Smoll, L.I., Sato, T., Layusa, C.A.A. and Acebes, J.M.V. 2020. Interchange of humpback whales (Megaptera novaeangliae) between northern Philippines and Ogasawara, Japan, has implications for conservation. Pac. Conserv. Biol. 26: 378-83. [Available at: https://doi.org/10.1071/PC19003].

Nishiwaki, M. 1959. Humpback whales in Ryukyuan waters. Sci. Rep. Whales Res. Inst., Tokyo 14: 49-87.

Nishiwaki, M. 1960. Ryukyuan humpbach whaling in 1960. Sci. Rep. Whales Res. Inst., Tokyo 15: 1-16.

Nishiwaki, M. 1961. Ryukyuan whaling in 1961. Sci. Rep. Whales Res. Inst., Tokyo 16: 19-28.

Nishiwaki, M. 1966. Distribution and migration of the larger cetaceans in the North Pacific as shown by Japanese whaling results. pp.17191. In: Norris, K.S. (eds). Whales, Dolphins and Porpoises. University of California, Berkeley and Los Angeles. xv+789pp.

NMFS and NOAA. 2016. Endangered and threatened species; identification of 14 distinct population segments of the humpback whale (Megaptera novaeangliae) and revision of species-wide listing. Fed Regist 81: 62259. [Available at: www.gpo.gov/fdsys/pkg/FR-201609-08/pdf/2016-21276.pdf].

Silberg, J.N., Acebes, J.M.V., Burdin, A.M., Mamaev, E.G., Dolan, K.C., Layusa, C.A. and Aca, E.Q. 2013. New insight into migration patterns of western North Pacific humpback whales between the Babuyan Islands, Philippines and the Commander Islands, Russia. J. Cetacean Res. Manage. 13(1): 53-57.

Titova, O.V., Filatova, O.A., Fedutin, I.D., Ovsyanikova, E.N., Okabe, H., Kobayashi, N., Acebes, J.M.V., Burdin, A. and Hoyt, E. 2018. Photoidentification matches of humpback whales (Megaptera novaeangliae) from feeding areas in Russian Far East seas and breeding grounds in the North Pacific. Mar. Mamm. Sci. 34: 100-12. [Available at: $h$ ttps://doi.org/10.1111/mms.12444].

Uchida, S. 1997. Surveys of cetaceans in the Japanese waters. pp.18-25. In: S. Uchida (ed.). Kings of the Sea: Humpback Whales: A 19911995 Survey of Cetaceans in the Japanese Waters. The UFJ Environment Foundation.

Uchida, S., Higashi, N., Maeda, H., Koido, T. and Takemura, A. 2005. What is a humpback whale? pp.6-17. In: S. Uchida (eds). Kings of the Sea: Humpback Whales II: A 1999-2005 Survey of Cetaceans in the Japanese Waters. The UFJ Environment Foundation.

Urban, J. and Aguayo, A. 1987. Spatial and seasonal distribution of the humpback whale, Megaptera novaeangliae, in the Mexican Pacific. Mar. Mamm. Sci. 3(4): 333-44.

Wade, P.R., Quinn, T.J., II, Barlow, J., Baker, C.S., Burdin, A.M., Calambokidis, J., Clapham, P.J., Falcone, E.A., Ford, J.K.B., Gabriele, C.M., Mattila, D.K., Rojas-Bracho, L., Straley, J.M., Taylor, B.L., Urbán R., J., Weller, D., Witteveen, B.H. and Yamaguchi, M. 2016. Estimates of abundance and migratory destination for North Pacific humpback whales in both summer feeding areas and winter mating and calving areas. Paper SC/66b/IA21 presented to the IWC Scientific Committee, June 2016, Bled, Slovenia (unpublished). 42pp. [Paper available from the Office of this Journal].

Witteveen, B.H., Worthy, G.A.J. and Roth, J.D. 2009. Tracing migratory movements of breeding North Pacific humpback whales using stable isotope analysis Mar. Ecol. Prog. Ser. 393: 173-83. [Available at: $h$ ttps://doi.org/10.3354/meps08231].

Yamaguchi, M., Acebes, J.M. and Miyamura, Y. 2002. The breeding ground distribution of the humpback whales, Megaptera novaeangliae, in the western North Pacific and their trans-movements among the Ogasawara Islands, the Ryukyu Islands and the Philippines. Paper presented at the Second Conference on Marine Mammals of Southeast Asia, Dumaguete, Philippines, July 2002 (unpublished). [Available from mana@bonin-ocean.net].

Yamaguchi, M., Suganuma, H., Miyamura, Y., Sato, F. and Mori, K. 1995. The interchanges of humpback whales between wintering grounds in the western North Pacific: the Ogasawara Islands and the Kerama Islands, Ryukyu Archipelago, Florida. [Available from the author].

Yaptinchay, A.A. 1999. New humpback whale wintering ground in the Philippines. Paper presented to the 13th Biennial Conference on the Biology of Marine Mammals, 28 November-3 December 1999, Maui, Hawaii. 